They are on equally firm ground in urging that more should be done to encourage all apprantices to apply for deferment of their National Service until completion of their apprenticeships. This factual study and the restraint of its generalization put the problem of National Service into a true perspective in relation to man-power resources, and should stimulate further thought and effort to deal with the implications, both by the Services and by educational authorities and employers.

\title{
FINANCIAL RESPONSIBILITY IN BRITISH UNIVERSITIES
}

A TREASURY Minute*, dated January 31, 1957, appended to a Special Report from the Committee of Public Accounts for the session 1956-57, reiterates the Treasury's inability to concur in the Committee's recommendations that the Comptroller and Auditor General should be given right of access to such papers and records of the University Grants Committee as relate to non-recurrent grants. The Treasury shares the Committee's concern that the non-recurrent grants should be expended with economy and efficiency on the purposes for which they are given; but it has received explicit assurances both by the University Grants Committee and on behalf of the universities, that the obligation to observe the strictest canons of economy and of financial propriety is recognized as applying with even more than ordinary force to them, since public money is expended without being subject to the ordinary processes of financial control on behalf of the Government and Parliament.

The Treasury considers that, having regard to the special financial relation existing between the Government and the universities of Great Britain, the control exercised over the expenditure of nonrecurrent grants should involve determination by the Government of the total amount of commitments in a given year, and by the University Grants Committee of the projects on which this money may be spent, and approval by the Committee of the cost of all those projects. All appropriate measures to ensure economy in expenditure will be taken by the universities themselves. Further, the Treasury will be provided with information to show that the total commitments have not exceeded the sum approved and that the accounting officer is aware of the main projects on which the University Grants Committee has decided that the money should be spent. The Treasury will then be able to review the position in good time if the pattern of expenditure in a particular year seems likely to differ widely from that envisaged by Parliament in voting the grant.

As regards the last of these four points, the Treasury has been informed on behalf of the universities that it is intended that each university and university college in Britain should formally notify its auditor of every non-recurrent grant received and the purpose for which it was made, and request its auditor to certify in general terms whether every such grant

- Special Report from the Committee of Public Accounts : Treasury Minute and Abstract of Appropriation Accounts, Session 1956-57. Pp. 20. (I.ondon: H.M. Stationery Office, 1957.) 18. net. was duly applied to the purpose for which it was made.

In consultation with the University Grants Committee, the Treasury has also decided to make a number of changes, detailed in the Minute, which, it is believed, give reasonable assurance that this expenditure will be properly controlled and properly administered. Accordingly, the Treasury expresses the hope that the Committee of Public Accounts will not press its recommendation. The revised procedure will place on Treasury files quarterly statements obtained through the University Grants Committee showing the amounts paid in respect of each of the building projects detailed in the appropriate parts of the estimates. If, after the estimate for any year has been approved, the University Grants Committee wishes to alter the distribution of the non-recurrent grant by more than 10 per cent in any of the categories, it will first seek the agreement of the Treasury. The Committee will also inform the Treasury of decisions taken in respect of buildings to be started in any year and estimated to cost more than $£ 30,000$; and in recommending approval of a non-recurrent grant for a particular university, the statement forwarded to the Treasury will identify any such building project with the corresponding item in the programme already furnished. These statements will also show separately any increase in grant for such major projects already approved, distinguishing increases which are made in respect of increases in prices and wages.

Thus once again the question of the accountability of the universities of Great Britain to Parliament for some part at least of the substantial sums of public money provided for their use has been answered, and the Treasury has rightly refused to give way to the demands of the Comptroller and Auditor General. This officer is, of course, only carrying out his duty in making such recommendations, for his task is to see that monies voted by Parliament are being properly expended. Nevertheless, it has to be realized that the position of the universities is a special one, and any infringement of their autonomy, such as the suggested examination of their financial position by government officials, is an attack on the academic freedom so highly prized in the Western world. The Treasury has declared itself on the side of the universities; and it is to be hoped that the arrangements now announced will prevent the annual recurrence of this request for inspection of university accounts. 